\title{
Geodiversity from the perspective of the population of small cities: a case study in the Northeast of Brazil
}

\author{
A Geodiversidade na perspectiva da população de pequenas \\ cidades: um estudo de caso no nordeste do Brasil
}

\section{Geodiversidad en la perspectiva de la población de pequeñas ciudades: un estudio de caso en el noreste de Brasil}

\author{
Rafael Altoe Albani \\ http:/ / orcid.org/0000-0003-0223-5850 \\ geoalbani@outlook.com \\ Universidade Federal do Rio de Janeiro, UFRJ, Museu Nacional, Rio de Janeiro, RJ
}

Kátia Leite Mansur

http:/ / orcid.org/0000-0003-4151-7463

katia@geologia.ufrj.br

Universidade Federal do Rio de Janeiro, UFRJ, Rio de Janeiro, RJ

Ismar de Souza Carvalho

http:/ / orcid.org/0000-0002-1811-0588

ismar@geologia.ufrj.br

Universidade Federal do Rio de Janeiro, UFRJ, Rio de Janeiro, RJ

Wellington Francisco Sá dos Santos

http:/ / orcid.org/0000-0001-5847-4362

wfsasantos@gmail.com

Universidade do Estaddo do Rio de Janeiro, UERJ, Rio de Janeiro, RJ

\begin{abstract}
Geodiversity of value must be conserved and thus bring benefits to the local population. The goal of this study was to analyze the perception of João Dourado inhabitants regarding their geodiversity, as well as to seek suggestions from the residents on its geoconservation. The opinion survey was carried out with 280 residents and we found that 254 respondents understand that the city's rocks, water, and caves are considered as heritage and 231 believe that they may have associated economic value. Most people show confidence in the benefits that geodiversity could offer in economic and social terms, such as attracting geotourists to the city.
\end{abstract}

Keywords: Geoconservation, Opinion Survey, Geological Diversity. 
Resumo: A geodiversidade que possui valores precisa ser conservada e assim trazer benefícios para a população local. O objetivo deste estudo foi analisar a percepção dos habitantes de João Dourado a respeito da geodiversidade local e buscar sugestões dos moradores para sua geoconservação. Através de uma pesquisa de opinião com 280 moradores, encontramos que 254 entrevistados entendem que as rochas, a água e as cavernas da cidade são consideradas patrimônio e 231 acreditam que podem ter um valor econômico associado. A maioria das pessoas demonstra confiança nos benefícios que a geodiversidade pode proporcionar em termos econômicos e sociais, como a capacidade de atrair geoturistas para o município.

Palavras-chave: Geoconservação, Pesquisa de Opinião, Diversidade Geológica.

Resumen: La geodiversidad que tiene valores necesita ser conservada y, por lo tanto, traer beneficios a la población del lugar. El objetivo de este estudio fue analizar la percepción de los habitantes de João Dourado con respecto a la geodiversidad local, así como buscar sugerencias de los residentes para su geoconservación. Para esto se realizó una encuesta de opinión con 280 habitantes del municipio. Los resultados muestran que 254 entrevistados entienden que las rocas, el agua y las cuevas de la ciudad se consideran patrimonio y 231 creen que pueden tener un valor económico asociado. La mayoría de las personas muestran confianza en los beneficios que la geodiversidad puede proporcionar en términos económicos y sociales, como la capacidad de atraer geoturistas al municipio.

Palabras clave: Geoconservación, Encuesta de Opinión, Diversidad Geológica.

\section{INTRODUCTION}

The local population should know its natural biodiversity and geodiversity. However, for the most part, people are unaware of these occurrences. For Salvan (1991), this constitutes an obstacle to conservation. Erikstad (2013) emphasizes that geoconservation is very close to the conservation and management of biodiversity and so both must go together for nature conservation. Geoconservation includes activities designed to conserve and protect geological features and processes for the benefit of future generations (Worton, 2008). For Mansur (2010), such benefits bring direct gains for the cities and the well-being of residents and visitors, through geotourism for instance.

The diversity of nature, encompassing both biotic and abiotic elements, forms the basis for the sustainability of society (Brilha, Gray, Pereira, \& Pereira, 2018). In a more general view, Gray (2008) considers geodiversity as the abiotic equivalent of biodiversity. For Serrano and Ruiz-Flaño (2007), this includes systems generated by both natural and anthropic processes, which consist of diversity at various scales, from particles to elements, places, and landscapes.

Aiming to promote the geoconservation, scientists have been aware people that geodiversity is a value to all society nevertheless endangered. Raising awareness of the public of the importance of these special places for science, education, and tourism is an effective strategy. As such, several studies relate local geodiversity to the surrounding population, as Potter (2005), Burek and Potter (2006), Santos \& Carvalho (2011), Burek 
(2012), Santos and Carvalho (2013a, 2013b), Castro, Mansur and Carvalho (2016), Pimentel et al. (2018), Da Silva (2019) and Santos, Carvalho and Brilha (2019).

Brazil is a country of magnificent geodiversity (Schobbenhaus \& Silva, 2012) and there is a need to check the perceptions and opinions of the inhabitants of João Dourado on geodiversity understanding, mainly the surrounding population, which maintain almost daily contact with the geoforms. Such people should be understood as potential partners in their defense (Castro, Mansur, \& Carvalho, 2016). To ascertain the interviewees' knowledge on local geodiversity and their notion of heritage, it is recommended the use of questionnaires through an opinion survey, as well as suggestions for its geoconservation, the possibility of benefits from geotourism, as well as suggestions for preserving, valuing and promoting aspects of geodiversity in João Dourado

The city is far $452 \mathrm{~km}$ from Salvador, in the microregion of Irecê, Central North Bahia (Fig. 1). It is part of the 'Polígono das Secas', an area recognized by Lei no. 1.348/51 as subject to prolonged drought and subject to special measures of the public administration. Even so, due to its supply of water from numerous wells, the municipality's economy is based on the irrigated cultivation of agricultural crops such as onion, carrots, beet, and beans. Its area is close to $913 \mathrm{~km}^{2}$ (Instituto Brasileiro de Geografia e Estatística [IBGE], 2018) and can be accessed from Salvador via the BR-324 highway to Feira de Santana and then the 'Rodovia do Feijão' highway BA-052.

Figure 1. Municipality of João Dourado, BA, and the mentioned localities.

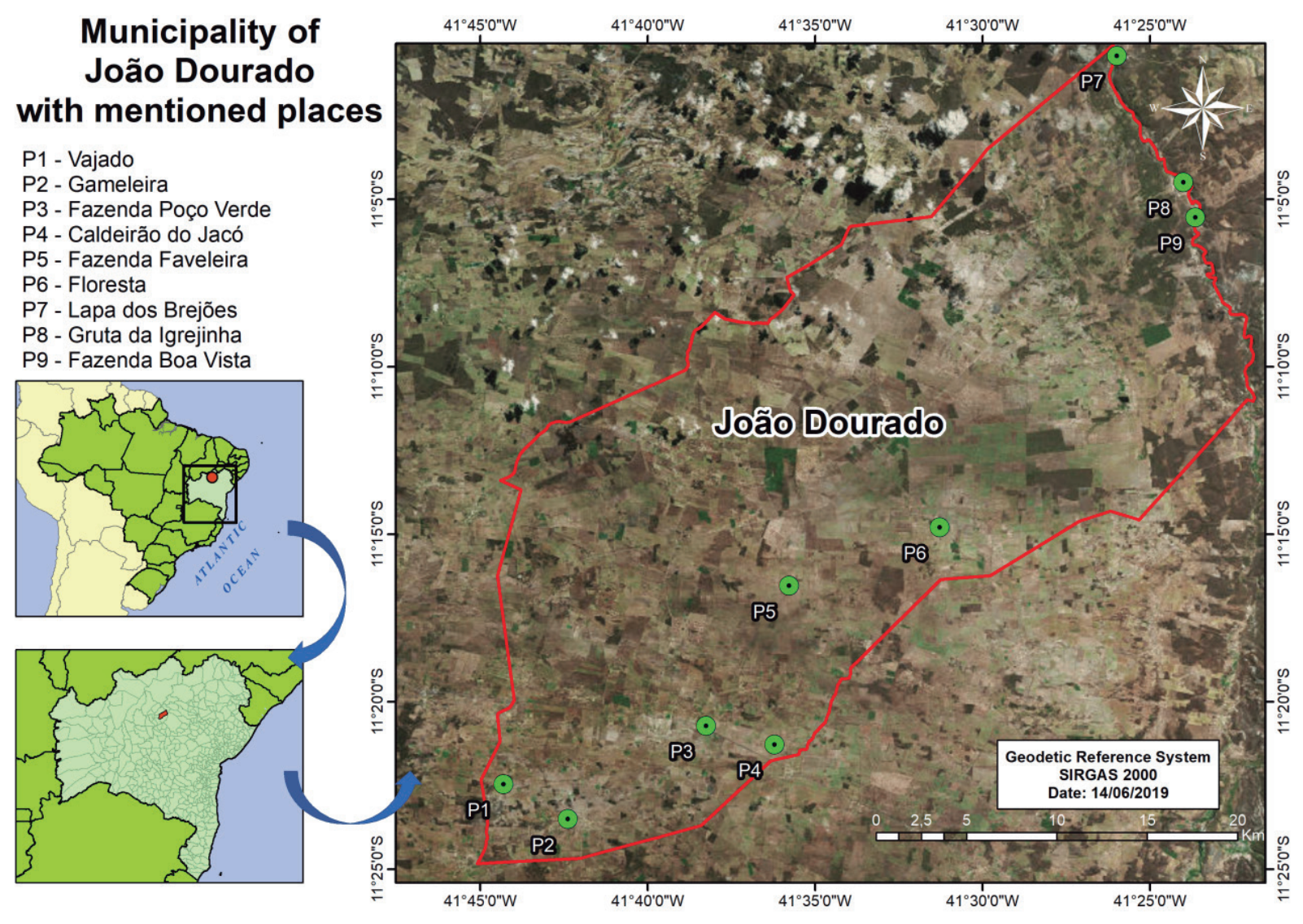


Its territory consists mainly of rocks of Neoproterozoic age outcropping from the Salitre Formation and belonging to the sedimentary basin of Irecê. It presents features of karst relief characterized by dissolution structures such as karrens, poljes, caves, and dolines (Serviço Geológico do Brasil [CPRM], 1985; Fragoso, Reis, \& Kuchenbecker, 2008). Tourism in the region is concentrated in the Environmental Protection Area of 'Lapa dos Brejões Vereda do Romão Gramacho', created by State Decree 32.487/85 for the preservation of the Lapa dos Brejões cave, archaeological and paleontological sites, ecosystems and local culture.

\section{MATERIALS AND METHODS}

Interviews were conducted through direct approaches to randomly selected residents of urban and rural areas of the municipality. The questionnaire has some closed-ended questions, others were open-ended, as well as mixed questions, to obtain justification, a contribution, or an opinion from the respondent, in addition to the standard closed responses. it is worth mentioning that a single interviewee was able to make more than one entry, causing the number of answers to exceed that of interviewees.

Between June 27th and July 3rd, 2016, it was interviewed 280 people, involving more than $1 \%$ of the population of the municipality, with 24,964 inhabitants (IBGE, 2018). It considered the urban population through home visits besides approaching passers-by in central places of great circulation. Traders were generally interviewed at their stores and the rural population at their properties.

The first part of the interview grouped information corresponding to the personal data, such as name, age, profession, gender, education, and income. By this, one could define different lifestyles and personal experiences as well as to draw up the socio-economic profile of the community. Age data were separated into age groups once one cannot expect the same level of understanding between people of different age groups. Thus, Sturges' Rule (Falco, 2008) was used to define the age intervals in the sample.

The second part of the interview focused on questions related to local geodiversity as interpreting their knowledge and perception on the existence of fossils, caves and rock paintings in the area; the antiquity of the rocks; the understanding of heritage; the association of heritage with economic value; weathered rocks, water, and caves could be considered heritage; if the municipality has the potential to receive geotourists and to build a museum; on the relationship between rocks and agriculture as well as proposals for the conservation, valorization, and promotion of local geodiversity. 


\section{RESULTS AND DISCUSSIONS}

\section{Sample Profile}

The sample corresponds to 172 males and 108 females, ranging from 16 to 97 years old. The application of Sturges' Rule led to the definition of nine age intervals. The largest group was aged between 16 - 25 (69 people), followed by 36 - 45 (60 people), 26 - 35 (59 people), 46 - 55 (35 people), 56 - 65 (30 people), 66 - 75 (16 people), 76 - 85 (8 people), 86 - 95 ( 2 people) and over 95 ( 1 person). So, the last five classes could be considered the elders one (57 people).

Related to education level, the classes are the following: illiterate (13 people), incomplete elementary school (70 people), incomplete secondary education (62 people), complete secondary education (84 people), incomplete undergraduate (17 people), complete undergraduate (21 people), and graduate (13 people). So, most ended their studies in elementary school or a couple of years more (132 people).

The sample occupation was farmers (83 people), salesmen (26 people), teachers (23 people), government employees (13 people), traders (13 people), part-time employed (62 people), students (37 people), retired (19 people), and unemployed (4 people).

Regarding income range: without income (37 people), up to $1 / 4$ of a minimum salary (8 people), between $1 / 4$ to half a minimum salary (14 people), between half to one minimum salary (109 people), 1 - 2 minimum salaries (78 people), 2 - 3 (19 people), and more than 3 (15 people), A large part of the population has low purchasing power and very few people receive more than three minimum salaries.

\section{Aspects related to Geodiversity}

\section{Existence of fossils}

Regarding the interviewees' knowledge of the existence of local fossils a little less than half (125 people) stated that they knew their existence, whereas 155 people do not know that fossils exist in the municipality. Among those who claimed to have heard of the existence of fossils, most mentioned 'Fazenda Faveleira' (Fig. 2A), 'Lapa dos Brejões', and 'Caldeirão do Jacó'. It is presumed that the greater knowledge of the people concerning the 'Fazenda Faveleira' site was due to the paleontological discoveries of the Quaternary megafauna in recent years (Faria, 2016), their disclosure in the local media and public open lectures. The 'Gameleira', 'Vajado', 'Floresta' (Fig. 2B), 'Fazenda Poço Verde' (Fig. 2C), and 'Gruta da Igrejinha' sites were mentioned by a smaller number of people (Fig. 5A). 
Figure 2. A: Paleontological excavation at 'Fazenda Faveleira' (Faria, 2016); B: Fossils gathered in the backyard of a property in 'Floresta'; C: Fragments of fossilized bones found at 'Fazenda Poço Verde'.
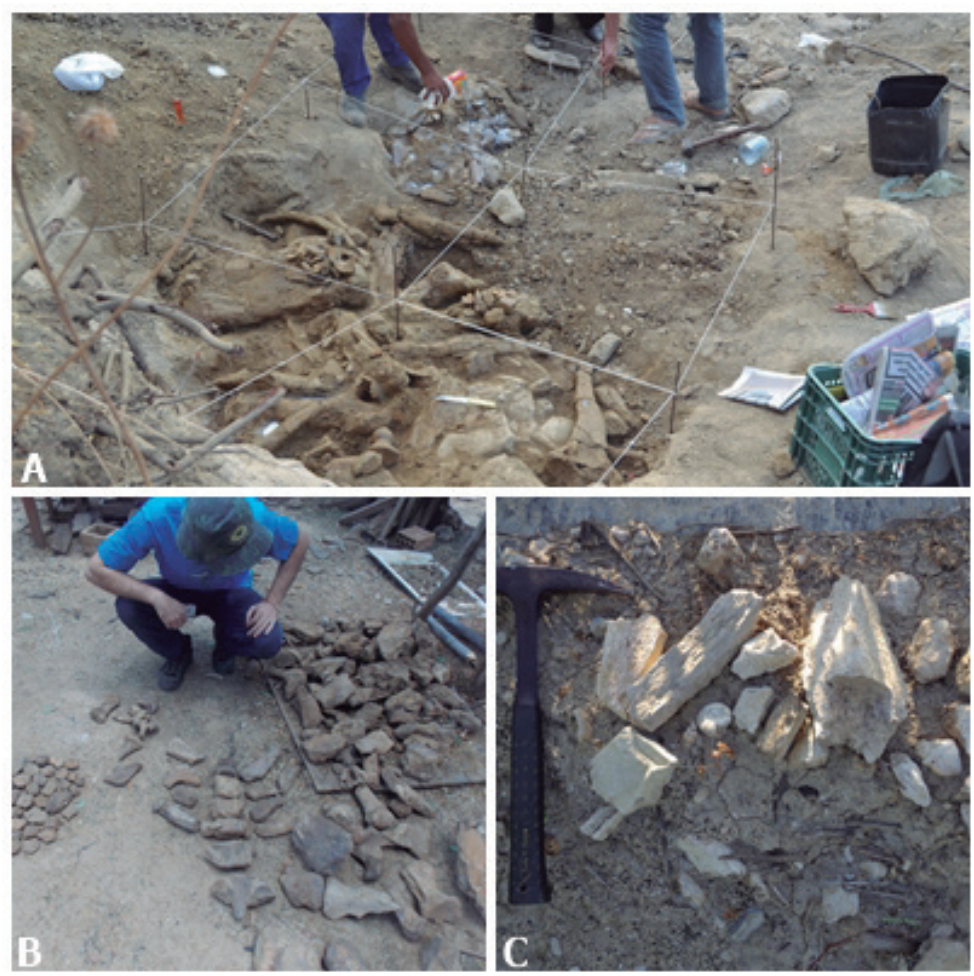

'Lapa dos Brejões' is located in two other municipalities, in addition to João Dourado, is part of the proposed area for the implementation of the 'Morro do Chapéu' Geopark (Rocha \& Pedreira, 2013), being considered as local-type due to the occurrence of the holotype Racekiela cavernicola n. sp. (Volkmer-Ribeiro, Bichuette, \& De Sousa Machado, 2010). Despite the existence of international scientific articles on the site (Courbon \& Chabert, 1986; Steadman et al., 2005; Barbosa \& Travassos, 2008; Marcolino et al., 2012), it is considered the major contributor to the number of mentions the location's attractiveness to tourists.

At Caldeirão do Jacó town there is a private property with pottery activities. According to the owner, fossils were removed at the beginning of 2015, but he could not say who had removed them or which institution was responsible for collecting the fossiliferous material. Until June 2019 no publications regarding material removed from the location had been found. Most of the people who mentioned this site do live in this settlement and possibly have known about it from their neighbors.

\section{Existence of caves}

Regarding the knowledge on the existence of caves in the area, most (198 people) stated that they knew about them and cited 'Lapa dos Brejões' as an example. 'Gruta da Igrejinha' was cited by a small number of people while 'Gameleira' and 'Vajado' sites were also mentioned by a smaller portion of the interviewees (Fig. 5B).

'Lapa dos Brejões' (Fig. 3A) was cited at the same time people recognize it for its fossils. This cave stands out on the national speleological scene due to the vast extent of 
its galleries, the dimensions of its speleothems, the volume of its sinking dolines, and the spectacular portal of 106 meters height, all of aspects of unquestionable tourist appeal (Berbert-Born \& Karmann, 2002).

In the village of Angicão, 'Gruta da Igrejinha' (Fig. 3B) is inserted in a karst valley of difficult access due to the volume of water of Jacaré river, seldom visited. Thus, it is amazing and highly satisfactory for it to be listed as the second most cited. Like 'Lapa dos Brejões', this cave is inserted in the Environmental Protection Area 'Lapa dos Brejões - Vereda do Romão Gramacho'.

In both the 'Gameleira' and 'Vajado' settlements, places less mentioned by the interviewees, there are no caves although the local population has stated knowing the existence of caves at these sites.

Figure 3. A: 106m height 'Lapa dos Brejões' entrance porch; B: Stalactites at the entrance to 'Gruta da Igrejinha'.
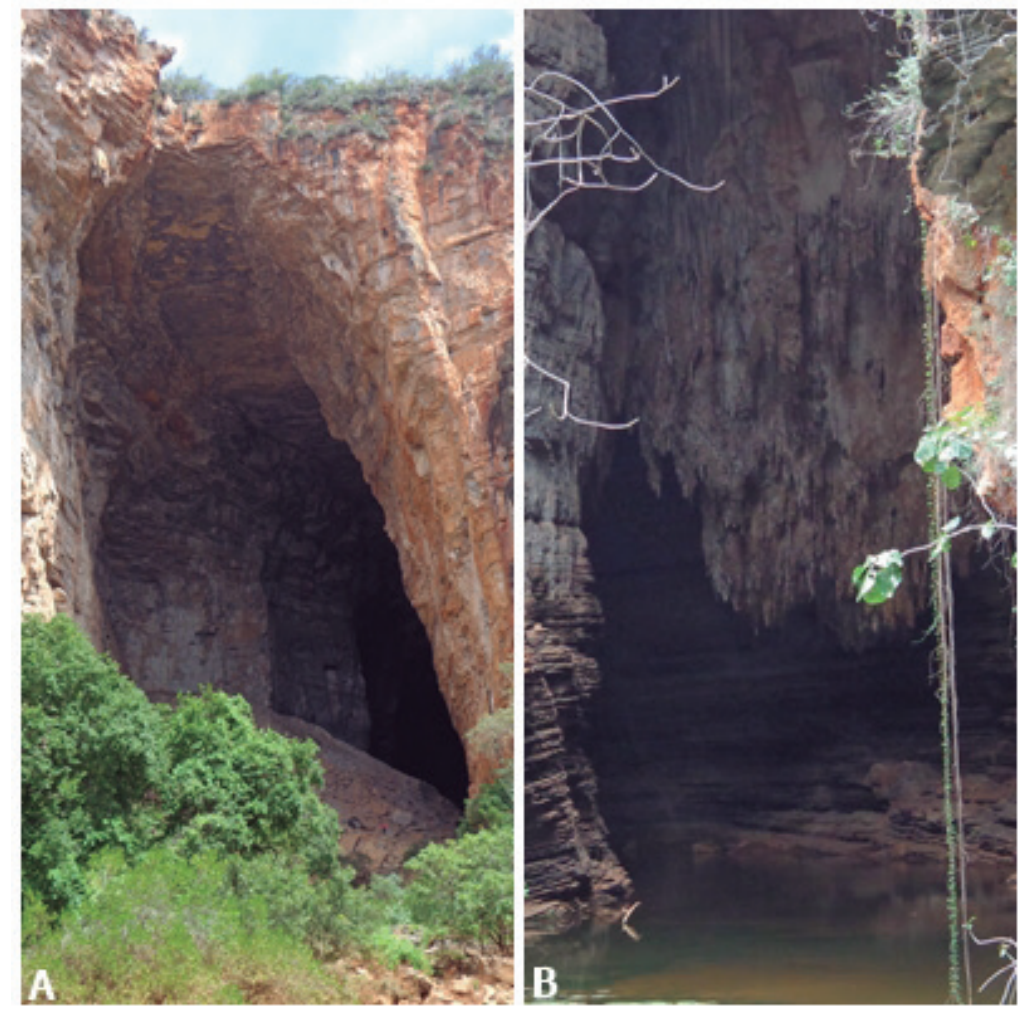

\section{Existence of rock paintings}

It is important to point out that 'Fazenda Boa Vista' presents several rock paintings (Fig. 4) but it was not mentioned by any of the interviewees. Location information and photos were submitted to the National Institute of Historical and Artistic Heritage to record and further archaeological research.

Concerning rock paintings in the area, 106 interviewees have heard of their occurrence in 'Lapa dos Brejões', 'Gruta da Igrejinha', 'Gameleira', and 'Vajado' (Fig. 5C). 
Figure 4. A and B: Rock paintings at 'Fazenda Boa Vista'.

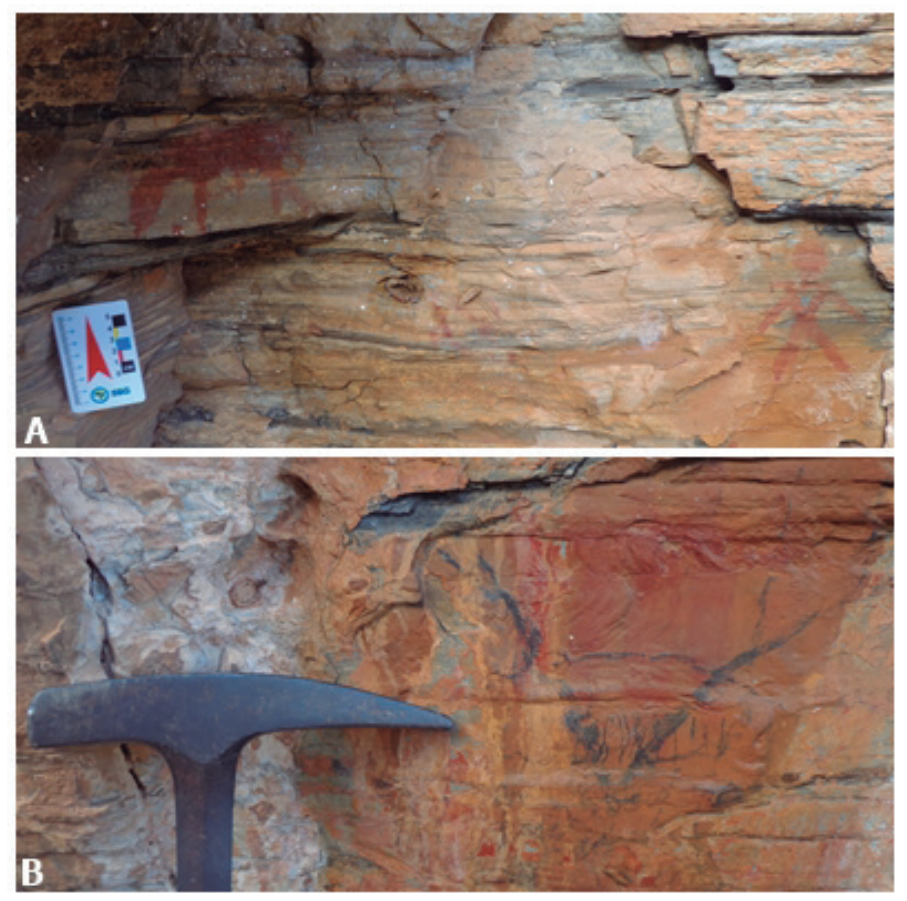

\section{Antiquity of the rocks}

It was asked: "Do you think the stones of João Dourado are very old?" As it was a complex question, people were not completely sure of the answer, clearly pointed by the division of opinions. Only 18 people answered that the rocks of the municipality are not ancient; 262 were equally divided as to the very age of the rocks; 34 think they are billions of years old; 85 people quoted millions of years; 62 said they are thousands of years old; 79 believe they are just hundreds of years old, and 6 have no idea about their age. As a matter of fact, according to Alkmin (2004), the estimated maximum age for the Salitre Formation is 720 Ma. 
Figure 5. The absolute number of answers related to sites containing: (A) fossils, (B) caves, and (C) rock paintings in João Dourado; as well as to the measures considering: (D) valorization and promotion, (E) conservation of the local geodiversity.
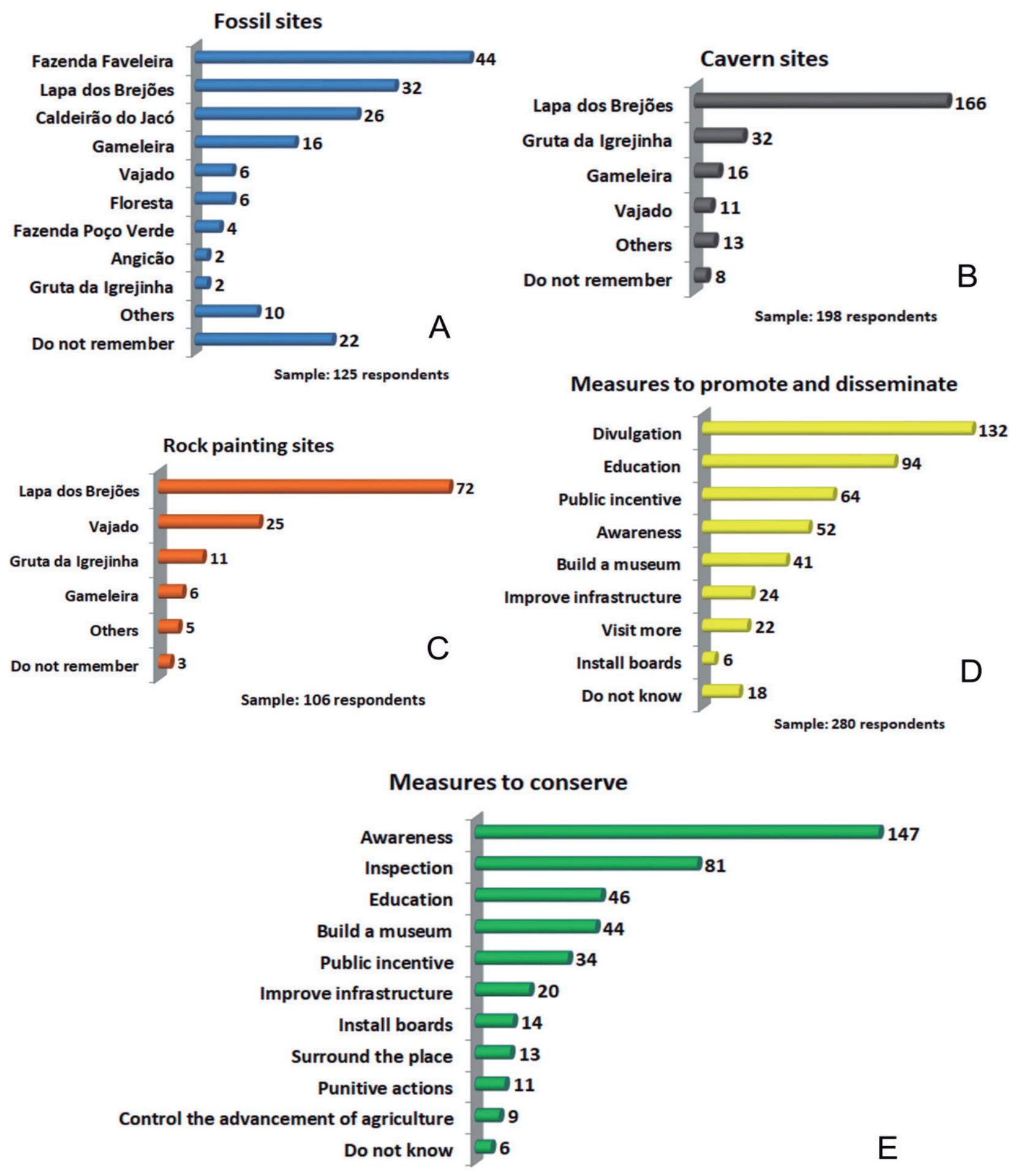

Sample: 280 respondents 


\section{Understanding heritage}

Understanding heritage in a broad sense, when asked to define heritage in a few words the answers were grouped into the following categories: asset, legacy, wealth, something old, something public, identity/history (more others and do not know). The majority (197 people) associate heritage with asset, inheritance, or wealth. A total of 33 people said that heritage refers to the identity or history of something; 21 mentioned something public, and 11 something old. Each of the following had one citation: irrigation, good place, 'Lapa dos Brejões', João Dourado, homeland, settlement, and nature. A total of 20 participants in the study could not provide any meaning for heritage.

In a study carried out with the population of the municipality of Santana do Cariri (Ceará), Castro, Mansur \& Carvalho (2016) emphasized that the moment a respondent defines heritage, an important relationship is established, and it reflects the person values. Knowing these values helps to understand why some preservation difficulties occur and also helps in the elaboration of strategies to mitigate such problems.

\section{Associating heritage to the economic value}

When asked: "Does heritage mean economic value? Why?", 231 people claimed that heritage means economic value, and 171 justified it by saying that it involves money and can generate income, while 44 said it has to do with identity/culture and the possibility of attracting tourists. However, 14 people did not answer at all and 2 interviewees mentioned vaguely the possibility of heritage staying forever and bringing benefits.

Among those who answered that heritage does not mean economic value, 45 people said that heritage is related to the identity/culture of a people and has no direct link with economic value. Other answers (3) were "because it doesn't", "because it does not generate money for anyone" and "because it does not bring benefits". One person was unable to justify their answer.

\section{Rocks, water and caves as heritage}

Relating to the significance of rocks, fossils, groundwater, and caves as heritage, only 26 have said "no significance" but they did not know how to justify it. To the others, it is "because it belongs to the municipality" (65 people), "because it is rare" (58 people), "because it belongs to nature" (39 people), "because it is a source of income" (38 people), "because it generates employment" (24 people), "because it attracts tourists" (21 people), "because it demands a lot of effort to get it" (1 person), "because it is the identity of a people" (1 person), "because it belongs to all" (1 person), "because it has a historical and social value" (1 person), while 5 participants were unable to answer.

\section{Potential for geotourism}

About the possibility of the municipality receiving geotourists, the following question was asked: "Do you think João Dourado has the potential to receive tourists interested in rocks, 
fossils, and caves? Why?" The 202 people who answered "yes" justified their answers as follows: "because they have something to explore" (165 people), "because there are qualified people" (21 people) and "because the municipality has adequate infrastructure" (16 people). On the other hand, 78 respondents answered " $n o$ " for the following reasons: "inadequate infrastructure" (36 people), "government disinterest" (31 people), "lack of disclosure" (10 people), "there is nothing to explore" (1 person), "there is no natural beauty in the municipality" (1 person), "lack of knowledge of the population" (1 person), "deforestation has finished with the municipality" (1 person), "there is not a great deal of geological diversity" (1 person) and 19 did not justify their opinion.

These results indicate that the majority of respondents believe in the potential of the municipality to attract geotourists, mainly due to the existence of possible sites that would benefit from geotourism, as well as there are infrastructure and skilled people in the town for this purpose.

\section{Potential for a museum creation and its relationship with the tourism growth}

When questioned if they had visited a museum, 162 had never visited one yet and 118 said "yes". They were also questioned about the possibility of the municipality housing a museum focused on the natural aspects of the region. The vast majority (236 people) agreed that João Dourado could host a museum and 44 people disapproved of the idea. This question did not require justification, but some interviewees spontaneously justified that the municipality could not house a museum "because nothing is interesting here", "the municipality is very weak", "it is weak, there is nothing here", "there isn't a good representative", "there is no government incentive", "there is no interest in it", "because the city is small", "because there is little here", "because there are no explorers", "because there is no cultural interest", and "because there is no infrastructure".

Part of the population does not know the importance of creating a museum (remembering that most of the interviewees have never visited one), besides not knowing the municipality itself nor its natural wealth. Besides survey participants were also asked if the construction of a museum focused on the natural aspects of João Dourado would increase the number of tourists in the municipality. Most interviewees (244 people) believe that the museum would attract more tourists to the town but 36 people did not have the same expectation.

\section{$\underline{\text { Relationship between rocks and agriculture }}$}

The major (186 people) believe that there is a relationship between rocks and agriculture while the remaining 94 people see no relationship between them. This item focused on the understanding of the interviewees as to soil fertility and the existing groundwater reserve. Although it is a rather complex question for those who do not have known geosciences, most of the interviewees were able to see this relationship. It is presumed that empirical knowledge may have contributed to the majority seeing this relationship since it is a predominantly agricultural region. 


\section{Measures to value and disseminate}

To know the opinion of the interviewees as to what needs to be done to value and promote the natural aspects of João Dourado, an open-ended question was asked on the subject. The data were grouped into the following categories: "awareness", "public incentives/ local guides", "promotion", "research/lectures", "improve infrastructure", "build a museum", "install boards", "visit more" and "do not know".

According to Figure 5D, most of the interviewees suggested promotion in the local media (TV João Dourado and Lucas Souza Publicity), lectures and research in the municipality, government incentives with the deployment of tourist guides, greater awareness-raising and the construction of a museum. A smaller number of respondents suggested improving infrastructure (roads, hotels, restaurants, places to welcome the visitors, etc.), visiting more sites since people would recommend others to visit also, and the installation of explanatory panels.

\section{Measures to conserve}

To that answers the data were grouped into the following categories: "awareness/ care/belonging", "inspection", "public incentive", "improve infrastructure", "build a museum", "education" "control the advance of agriculture," "install boards," "punitive actions", "surround the place," and "do not know."

Figure 5E demonstrates that most of the people answered that there should be greater awareness-raising and a greater sense of belonging about the natural elements, more supervision to prevent people from destroying these elements, more studies in the municipality, and also the construction of a museum would contribute to this goal. Other answered that there is a need for public incentives, to improve infrastructure, to install panels, to enclosure the areas to protect them, to establish actions to punish those who damage such places, to control the progress of agriculture and related activities such as disorderly drilling of wells, the use of agrochemicals and the soil erosion.

\section{FINAL REMARKS}

According to the results, it was possible to know how the population relates the surrounding geodiversity to strategies that could help its conservation, valorization, and promotion. The results provide a better understanding of the knowledge and opinion of the population of João Dourado relating to the existing geodiversity in the area. The scarcity of actions aimed at conservation, valorization, and promotion in most of the places reported by the interviewees is regrettable, bringing negative consequences not only for the sites themselves but also for the population involved.

However, the participants believe that certain actions could reverse this situation and contribute to the geodiversity maintenance of João Dourado, bringing benefits to the municipality. The most quoted measures were greater awareness-raising, both on the 
part of the residents and the visitors; public incentives for the installation of information boards; training of tourist guides; improved infrastructure; promotion and inspection of the sites; encouragement of lectures and scientific research; construction of a museum; and arising people interest in to know more about the natural attractions of the municipality.

Furthermore, the majority of respondents recognize that the municipality would benefit from activities linked to geotourism in addition to the 'Lapa dos Brejões', already well-known to tourists, once there are other sites to be visited as appropriate infrastructure and qualified people to attend the visitors were provided.

With a predominantly agricultural economy, João Dourado could benefit from an increase in the number of visitors, with the possibility of generating income for the local population. It is important to emphasize that to insert these 'new' locations into the regional tourist scene, it is indispensable to make visitors and residents become users and guardians of these places to avoid further damage, so that in the future they may continue to enjoy the same attractions found by now.

It should be emphasized that some of the people interviewed are unaware of elements associated with the geodiversity existing in João Dourado. Less than half of the respondents claimed to know the occurrence of fossils, most had never heard of the rock paintings, and part of them did not know that there are caves in the municipality. It is imperative to provide access to knowledge on the importance of these places and their elements so that the population of the municipality itself can give the proper value and, consequently, conserve its heritage.

\section{ACKNOWLEDGMENTS}

We thank the population of João Dourado for its engagement in the research and the MSc. Tatiane Ferrari do Vale for the support in the figures of this paper. We also thank the geologists Antonio José Dourado Rocha (CPRM) and Juracy Dourado Loula, and the environmental inspector Paulo Tertuliano dos Santos for their support in the fieldwork. This research was supported by the National Council for Scientific and Technological Development (CNPq), Rio de Janeiro Research Foundation (FAPERJ) and the Municipality of João Dourado.

\section{REFERENCES}

Alkmin, Fernando Flecha. (2004). O que faz de um cráton um cráton? O Cráton São Francisco e as revelações Almeidianas ao delimitá-lo. In. V. Mantesso-Neto, A. Bartorelli, C.D.R. Carneiro, \& B.B. Brito-Neves (Orgs.), Geologia do Continente Sul-Americano: evolução da obra de Fernando Flávio Marques de Almeida. (pp.17-35). São Paulo: Beca.

Barbosa, Elvis Pereira, \& Travassos, Luiz Eduardo Panisset. (2008). Caves, stories, history and popular traditions in the semi-desert (sertão) of Bahia, northeastern Brazil. Acta Carstologica, 37(2-3), 331-338. 
Berbert-Born, Mylène, \& Karmann, Ivo. (2002). Lapa dos Brejões - Vereda Romão Gramacho, Chapada Diamantina, BA - Gigantesca caverna e vale cárstico com rico depósito de fósseis do Quaternário. In C. Schobbenhaus et al. (Ed.), Sítios Geológicos e Paleontológicos do Brasil.(pp.469-479). Brasilia: DNPM/CPRM.

Brilha, José, Gray, Murray, Pereira, Diamantino Insua, \& Pereira, Paulo. (2018). Geodiversity: An integrative review as a contribution to the sustainable management of the whole of nature. Environmental Science and Policy,86, 19-28.

Burek, Cynthia V., \& Potter, Jacqueline. (2006). Local geodiversity action plans-setting to context for geological conservation. Chester: English Nature.

Burek, Cynthia V. (2012). The role of LGAPs (Local Geodiversity Action Plans) and Welsh RIGS as local drivers for geoconservation within geotourism in Wales. Geoheritage.4(1-2), 45-63.

Castro, Aline Rocha de Souza Ferreira, Mansur, Kátia Leite, \& Carvalho, Ismar.de Souza (2016). Diagnóstico da relação da comunidade com o patrimônio geológico por meio de instrumento de coleta de dados. Terræ Didatica, 11(3), 162-172.

Courbon, Paul, \& Chabert, Claude. (1986). Atlas des grandes cavités mondiales. Paris: L'Union Internationale de Spéléologie et de la Fédération Française de Spéléologie.

Da Silva, Carlos Marques. (2019). Geodiversity and Sense of Place: Local Identity Geological Elements in Portuguese Municipal Heraldry. Geoheritage,11(3), 949-960.

Erikstad, Lars. (2013). Geoheritage and geodiversity management - the questions for tomorrow. Proceedings of the Geologists' Association, 124(4), 713-719.

Falco, Javert Guimarães. (2008). Estatística aplicada. Cuiabá: Ed. UFMT. Retrieved from http:/ / proedu.rnp. br/bitstream/handle/123456789/547/ESTATISTICA_APLICADA.pdf?sequence=1

Faria, Fábio Henrique Cortes (2016). Análise das feições de modificação óssea nos fósseis da megafauna quaternária do Lajedão do Patrício, João Dourado, Bahia, Brasil. (Dissertação de Mestrado). Universidade Federal do Rio de Janeiro, UFRJ, Rio de Janeiro, RJ, Brasil.

Fragoso, Daniel Galvão Carnier, Reis, Humberto Luis Siqueira, \& Kuchenbecker, Matheus. (2008). Mapeamento Geológico da região de Irecê-Lapão (BA): registros de uma rampa carbonática neoproterozóica. (Monografia de conclusão de curso), Universidade Federal de Minas Gerais - UFMG, Belo Horizonte, MG, Brasil.

Gray, Murray. (2008). Geodiversity: the origin and evolution of a paradigm. Geological Society, 300(1), 31-36. Instituto Brasileiro de Geografia e Estatística. (2018). Cidade de João Dourado, estado da Bahia. Retrieved from https:/ / cidades.ibge.gov.br/brasil/ba/joao-dourado/panorama.

Lei $n^{0} 1.348$, de 10 de fevereiro de 1951. Dispõe sobre a revisão dos limites da área do polígono das secas. Retrieved from http://www.planalto.gov.br/ccivil_03/LEIS/L1348.htm.

Mansur, Kátia Leite. (2010). Diretrizes para geoconservação do patrimônio geológico do Estado do Rio de Janeiro: o caso do Domínio Tectônico Cabo Frio. (Tese de Doutorado), Universidade Federal do Rio de Janeiro - UFRJ, Rio de Janeiro, RJ, Brasil. Retrieved from http://arquivos.proderj.rj.gov.br/inea_imagens/downloads/ pesquisas/PE_Costa_do_Sol/Mansur_2010.pdf

Marcolino, Camilla Pires, Isaias, Rosy Mary dos Santos, \& Cozzuol, Mario Alberto et al. (2012). Diet of Palaeolama major (Camelidae) of Bahia, Brazil, inferred from coprolites. Quaternary International, 278, 81-86.

Pimentel, Carla Silvia, Liccardo, Antonio, Maieski, Kleverson Gonçalves, \& Mendes, Camila Priotto. (2018). Contribuições da educação não formal no aprendizado sobre Geodiversidade: Projeto Geodiversidade na Educação. Terræ Didatica, 14(3), 225-232.

Potter, Jacqueline. (2005). Local geodiversity action plans (LGAPs) and the community: The Cheshire region LGAP. Chester: English Nature.

Rocha, Antonio José Dourado, \& Pedreira, Augusto José. (2013). Geoparque Morro do Chapéu, Bahia (Proposta). In: Adalberto de Figueiredo Ribeiro. Geoparques do Brasil/Propostas. (Vol. 1, pp. 61-110). Salvador: CBPM. Retrieved from https:/ / docplayer.com.br/4613084-4geoparque-morro-do-chapeu-ba-proposta.html 
Salvan, Henri. (1991, junho). Un problème d'actualité: la sauvegarde du patrimoine géologique. Quelques réflexions. Actes do Premier Symposium International sur la Protection du Patrimoine Geologique, Digne-lesBains, França, 1. Retrieved from https://lib.ugent.be/catalog/rug01:001040820

Santos, Wellington Francisco Sá dos, \& Carvalho, Ismar de Souza. (2011). Propostas para a preservação do Parque Paleontológico de São José de Itaboraí (Brasil) a partir da percepção populacional. Anuário do Instituto de Geociências, 34(2), 24-37.

Santos, Wellington Francisco Sá dos, \& Carvalho, Ismar de Souza. (2013a). Percepção dos professores do entorno do Parque Paleontológico de São José de Itaboraí (RJ) sobre aspectos geológicos, paleontológicos e arqueológicos locais. Terrae Didatica, 9(1), 50-62.

Santos, Wellington Francisco Sá dos, \& Carvalho, Ismar.de Souza (2013b). The public opinion of the teachers about the mineral exploitation in São José de Itaboraí Basin-Itaboraí (Rio de Janeiro State, Brazil). Rendiconti Online della Societa Geologica Italiana, 28, 133-136.

Santos, Wellington Francisco Sá dos, Carvalho, Ismar de Souza \& Brilha, José. (2019). Public Understanding on Geoconservation Strategies at the Passagem das Pedras Geosite, Paraíba (Brazil): Contribution to the Rio do Peixe Geopark Proposal. Geoheritage, 11(4), 2065-2077.

Schobbenhaus, Carlos, \& Silva, Cassio Roberto da. (2012). Geoparques do Brasil. (Vol. 1). Brasília: CPRM.

Serrano, Enrique, \& Ruiz-Flaño, P. (2007). Geodiversity: a theoretical and applied concept. Geographica Helvetica, 62(3), 140-147.

Serviço Geológico do Brasil. (1985). Relatório final do Projeto Bacia de Irecê. (Vol. 1). Brasília: CPRM.

Steadman, David W. et al. (2005). Asynchronous extinction of late Quaternary sloths on continents and islands. Proceedings of the National Academy of Sciences, 102(33), 11763-11768.

Volkmer-Ribeiro, Cecília, Bichuette, Maria Elina, \& De Sousa Machado, Vanessa. (2010). Racekiela cavernicola (Porifera: Demospongiae) new species and the first record of cave freshwater sponge from Brazil. Neotropical Biology and Conservation, 5(1), 53-58.

Worton, Graham J. (2008). A historical perspective on local communities and geological conservation. Geological Society, 300(1), 137-146.

Data de submissão: 30/ ago./ 2019

Data de aceite: 02/ set./ 2019 